FACTA UNIVERSITATIS

Series: Physical Education and Sport, Vol. 17, No 1, 2019, pp. 111 - 124

https://doi.org/10.22190/FUPES180531013P

Research article

\title{
ANALYSIS OF THE MOTOR STATUS OF YOUNGER SCHOOL AGE CHILDREN IN RELATION TO THEIR NUTRITIONAL STATUS
}

\author{
UDC 796.012-055.2 \\ 572.7.087-055.2
}

\section{Vladan Pelemiš́1, Darijan Ujsasi², Velibor Srdić ${ }^{3}$, Danica Džinović1, Slobodan Pavlović ${ }^{4}$}

${ }^{1}$ Teacher Education Faculty, University of Belgrade, Belgrade, Serbia

${ }^{2}$ Magic Kingdom Sport Club, Novi Sad, Serbia

${ }^{3}$ Faculty of Sport Science, PanEuropean University Apeiron, Banja Luka, Republic of Srpska, Bosnia and Herzegovina

${ }^{4}$ Faculty of Pedagogy in Užice, University of Kragujevac, Užice, Serbia

\begin{abstract}
The aim of the research is to determine whether there are gender differences between younger school-age children, and whether those differences within the subsample are influenced by the state of mass and motor skills. The whole sample included 285 respondents age $7.27 \pm 0.43$, of which 144 boys (50.52\%), and 141 girls (49.48\%) who attended the first grade on the territory of the Province of Vojvodina (Republic of Serbia). The Eurofit battery of tests was used. The research results show that the prevalence of children with severe thinness in the whole sample is low 3.87\%; children with normal mass $65.26 \%$; pre-obese children only $18.59 \%$ and obese children only $12.28 \%$, so that gender differences in motor skills considering the whole sample, apart from the mass, are between average values for boys considering explosive strength of the lower extremities, repetitive strength of the body and agility. Statistically significant differences within the sub-sample considering motor abilities were seen neither in boys nor in girls of different mass. The research findings show that there is significant percentage of children with normal mass and that the flow of their mass is within their growth and development. Their motor development within the sub-sample also flows equally, and gender differences are present because of differentiation of motor skills, which appears in this period. The authors think that greater differences and variables in respect to mass and motor activities are to be seen in the period of pre-puberty.
\end{abstract}

Key words: body mass index, differences, gender, motor skills

Received May 31, 2018 / Accepted May 09, 2019

Corresponding author: Vladan Pelemiš

University of Belgrade, Teacher Education Faculty, Kraljice Natalije 43, 11000 Belgrade, Serbia

Phone: +381 113615225 •E-mail: vladankinesiology77@gmail.com 


\section{INTRODUCTION}

A long time ago, the problem of physical (in)activity was identified by the National Association for Sport and Physical Education (NASPE, 2002), which issued guidelines for children in which there is the minimum of 60 minutes of daily planned physical activity. The guidelines were created by the Active Start Committee, which is currently giving the best recommendations considering the physical activities of children and as such it is unique in the world (Tucker, 2008). If we consider the very physical activity as a phenomenon, even in its basic form and not in the programmed and planned cycle, its significance for the health of the human population is immense. Physical activity is beneficial for health, both physical and mental (Warburton, Nicol, \& Bredin, 2006). Apart from prevention and reduction of overweight children and obesity, and this refers to 22 million children around the world (WHO, 2008), physical activity is beneficial for cardiovascular status, muscle strength and endurance, alleviating depression and anxiety, and even with a positive effect on academic achievements (Strong et al., 2005). It is not only desirable, but it is obligatory for several reasons: 1) habits gained in childhood remain as permanent ones, 2) the period of growth and development, particularly in the preschool age, is exceptionally suitable for the body to accept impulses which physical activities have on the development of anthropological characteristics and abilities, 3) prevents a negative appearance, which in this case occurs rarely in the period of puberty (obesity, attention disorder, etc.) (Jakšić, 2016).

On the other hand, it is possible to follow harmony and deviation of the children's development based on the gained motor skills and developed motor skills and fundamental factors of children's motor skills competencies, i.e., readiness (Pišot, \& Planinsec, 2010) . The level of development of motor skills of children significantly influences their further growth and development (Pelemiš, Branković, \& Banović, 2016). When younger primary school children are in question, motor skills have their particularities. In this period, motor abilities are characterised by significant variables, insufficiently built and insufficiently defined motor structures, which are still tightly connected. The development of motor abilities appears in accordance with certain regularities and it is similar to the ontogenetic development of the body (Šekeljić, 2014), and the main characteristics of the development are: hetero-chronology (intensive development in different periods), sin-phases (the development of abilities is overlapping), rhythm (appearance in a certain relatively correct rhythm) and sensibility (sensibility of the body to physical activities). Insufficient physical activity has been recognised as a risk factor and WHO (2000) states it as a risk factor of the same strength as previously hypertension and obesity had been (Pelemiš et al., 2015). This is why overweight children are prone to lesser physical activities (Planinšec, \& Matejek, 2004). These are the reasons which connect insufficient physical activity with enlarged obesity in children and this was pointed at by the research of Mendonca, \& Anjos (2004). Morphological fitness includes fatness factors, such as: the body mass index (BMI), fat tissue (subcutaneous and visceral), waist size, etc. (Malina, \& Katzmarzyk, 2006). Obesity indicators are often connected with the components of the metabolic form and with the components of the health form. The research shows that standard anthropometric methods for defining morphological types and determination of the structure still use $33 \%$, whereas the method of bioelectrical impedance (BIA) uses only $25 \%$ of all the used methods (Pelemiš, Macura, \& Branković, 2017). For these reasons, BMI is used as a good indicator 
and a signal for health risks, as well as growth and development of children, and it presents a significant indicator of the state of nourishment which this state brings (Janssen, Katzmarzyk, \& Ross, 2004). Also, the research conducted by Chiodera et al. (2008) showed that a specific programme of kinesis activities at school may improve the motor status of children without changing BMI values. Although it has been determined that BMI is negatively connected with the developments of motor skills in children (Bryant, Duncan, \& Birch, 2014), there is recent research which does not support it (Musalek, et al., 2017). The authors think that indexes such as BMI cannot identify the quantity of body fat, and it is essential in estimating motor skills. After recognising the findings of current research, a lack would be seen in the insufficient number of findings which point at the facts about whether and to which extent the state of nourishment influences the motor abilities of children. Considering the fact that the general public is more and more concerned about obesity in children and insufficient physical activity, there is an intensive tendency to follow obesity and improve the motor status of children (Burdyukova, Pustovalov, Oranskaya, Pertsov, \& Gurevich, 2012). This is why this study should give answers on questions whether the state of nourishment of children can determine their motor state.

The aim of the research was do determine whether there are gender differences between younger school-age children in terms of motor skills when BMI values are neglected, and whether the differences within the sub-samples are conditioned by their state of nourishment.

\section{METHODS}

The research had a transversal character. It was a project of non-experimental research, i.e. Ex post facto design. According to the postulates of the scientific research, the empirical method was used, according to the aim of implementing, the applicative method was used, whereas, according to the problem of recognition, the confirmative method was used. In accordance with the degree of control, the half-field method was used. The whole sample included 285 respondents, age 7.27 \pm 0.43 , of which 144 boys $[(50.52 \%)$ (average values $\mathrm{BH}=128.21 \mathrm{~cm}$ and $\mathrm{BW}=28.15 \mathrm{~kg})]$, and 141 girls $[(49.48 \%)$ average values $(\mathrm{BH}=126.92 \mathrm{~cm}$ and $\mathrm{BW}=27.16 \mathrm{~kg})]$ who attended the first grade in the territory of the province of Vojvodina (Republic of Serbia). Prior to the commencement of the research, the participants were informed about the course and the duration of the study, and given a written consent form to sign in accordance with the ethical principles for biomedical research on humans - Declaration of Helsinki (World Medical Association Declaration of Helsinki, 2013).

The study was longitudinal in character and empirical methods were used, while in accordance with the purpose of the method was applicative, confirmative in terms of the knowledge of the problem, and in relation to the degree of control, a laboratory method of research. A pre-experimental research draft was used (e.g. one group draft pre-testing post-testing).

As the sample of measurement instruments, modified tests were used, based on the Eurofit battery of tests, proposed by the Committee of sport development of the Council of Europe (Council of Europe, 1993). Estimation of anthropometric dimensions included measuring a single variable for estimating longitude dimension of the skeleton and that was 1) Body height $(\mathrm{cm})$; 2) Body mass $(\mathrm{kg})$ according to the international biological 
programme IBP for each measure. According to these two measured dimensions, 3) BMI $\left(\mathrm{kg} / \mathrm{m}^{2}\right)$ was calculated, according to the classification of the National Institutes of Health, National Heart, Lung, and Blood Institute (1998). Further on, respondents were grouped based on their referent values of BMI, and according to the percentile values proposed by the Centres for Disease Control and Prevention (2000) on the following sub-samples: 1) $\leq 5$ percentile-malnourished $(\mathrm{N}=11-3.87 \%) ; 2)$ 5-85 percentiles respondents with a normal scope of nourishment $(\mathrm{N}=186-65.26 \%)$; 3) 85.01-95 percentiles, at risk of obesity $(\mathrm{N}=53-18.59 \%)$ and 4$)$ over 95.01 percentiles were the respondents were overweight (obese) $(\mathrm{N}=35-12.28 \%)$.

Motor tests for estimating moving abilities included: estimation of speed of the alternative moving of arms 4) hand tapping (frequency); estimation of body balance 5) the Flamingo balance test (s); assessment of hamstring flexibility of the thigh; 6) the sit and reach test $(\mathrm{cm})$; assessment of explosive strength of the muscles of the legs; 7) the standing long jump; assessment of the strength of the trunk muscles; 8) sit-ups in 0s (frequency) and agility test and 9) shuttle run test $10 \times 5 \mathrm{~m}(\mathrm{~s})$.

Body height was measured by the anthropometric device by Martin. The respondent was barefoot. He/she stood on the flat surface with heels together, with his head in the position of the "Frankfurt horizontal". The distance between the surface and the top of the head was measured. The results were given in values of $0.1 \mathrm{~cm}$. Body mass was measured by the digital medical scale. The respondent was standing on the scale in his underwear. The result was given in values of $0.1 \mathrm{~kg}$.

Hand tapping was performed in front of the table with feet apart. The weaker hand was placed on the four square block in the centre. The stronger hand was placed on the opposite disc. The task was to touch the circles with the fingers of the dominant hand alternately, from the starting position in which the hands were crossed. When the start was announced, respondents were supposed to hit the blocks as fast as they could alternatively, in 25 cycles with two touches. The result was the time needed for 25 touches of each cycle, with a precision of a one tenth of a second. The Flamingo balance test was performed on a wooden board $50 \mathrm{~cm}$ in length and $3 \mathrm{~cm}$ in width, covered in fabric maximum $5 \mathrm{~mm}$ thick, tightly stuck to the board. Stability of the board was secured by two holders $15 \mathrm{~cm}$ long and $2 \mathrm{~cm}$ wide. The stop watch used did not have automatic return to the zero point, so measuring continued after starting the stop watch. The task of the respondent was to step with the dominant leg on the board, so that horizontal part of the foot was parallel with it. The free leg was bent at the knee and the foot was held with the hand of the same side. The task was to keep the balance on one foot as long as possible. When the respondent lost balance, the time would stop. After each brake in measuring time, it would be continued when the respondent had the right balance posture. This would be repeated until one minute had passed. A number of attempts were made, which were used for keeping balance for one minute. The Sit and reach test was performed in a seated position in front of the Swedish box with feet placed at the front part of the box. With hands spread (one on the other) in front of the body, the respondent bent his knees and bent forward for the purpose of pushing the slippery ruler without twitching. The result was determined by the furthest position which the respondent could reach with the top of his/her fingers. The test was performed slowly with advancing without a swing. The invigilator was kneeling next to the respondent and pressing his knees preventing him from moving his legs. The test was repeated twice and the best result was marked. The standing long jump was performed with both feet on take-off 
and lending. There were three jumps, and an inadequately performed jump was repeated. The best performed jump was marked. The measurement point was the point of the heel touching the surface which was closest to the take-off line. Moving from lying to sitting in 30s was performed in the initial position from lying in a supine position, hands at the occipital point and legs bent at the knees at an angle of $90^{\circ}$. The invigilator was held the legs, and the respondent, form a lying position tried to make a maximal numbers of raises in the front and in this way touch his knees with his elbows. The number of regularly performed raises from a lying position in 30 seconds determined the result. The Shuttle run test $10 \times 5 \mathrm{~m}$ was performed in the way that the respondent stood on the starting line and started to run as fast as possible at the marked track to the ending line at the other side of the track, he/she could pass with the foot of one foot and take the first sponge, then make a turn, return in the same direction, stand again with one foot over the starting line, leave the sponge and turn around to take another sponge, turn around and finished the test sprinting over the starting line. Time was measured in which a respondent passed the starting line at the beginning and ended when the respondent passed the line with fa ull foot after running 4 times the distance of $5 \mathrm{~m}$. Errors were made if the respondent crossed over the line with his foot or if he/she did not run along the right path and in this case measuring was repeated.

Medical decimal scales and anthropometry by Martin were used as measurement instruments, and the motor tests were performed by the stopwatch Polar C 112, frequency board for tapping, Swedish box, sliding ruler, mat, whistle, sticking coloured stripes, rug with marked lines in centimetres, spring board, metal measuring tape, plastic cones, sponges for cone drills.

Statistical data processing included the programme SPSS Statistics for Windows, version 11. All the data were calculated with the basic parameters of descriptive statistics: from measures of central tendency (M)-arithmetical means; from the variables measures (S)standard deviation. Further on, according to the percentile values, the respondents were divided into four categories: underweight, normal mass, pre-obese, and obese. The Multi variance analysis of the variance (MANOVA) method was used for determining gender differences in the whole motor area, and for the determining single differences the One-Way ANOVA method was used. After determining significant differences between the groups of respondents obtained on the state of nourishment with the serial Post Hoc tests by Bonferroni it will be determined between which groups there are significant differences.

\section{RESULTS}

Based on the values of the coefficient BMI in table 1, a classification was done where the respondents were later on grouped according to the percent values on the following sub samples: 1) $\leq 5$ percentiles-malnourished $(\mathrm{N}=11-3.87 \%)$; 2) from 5-85 percentiles were respondents with the normal scope of nourishment $(\mathrm{N}=186-65.26 \%)$; 3 ) from 85.0195 percentiles at risk of obesity $(\mathrm{N}=53-18.59 \%)$; and 4) over 95.01 percentiles were respondents who were overweight (obese) $(\mathrm{N}=35-12.28 \%)$.

Taking into account $\mathrm{F}$ values (table 2) it is concluded that there is a statistically significant difference $(\mathrm{P}=0.000)$ between the respondents of the different genders concerning their motor skills, if we were to look at the whole system of the applied variables. With a single observation, those differences are identified with the variables. The Standing long 
jump, sit-ups in $30 \mathrm{~s}$ and shuttle run test and boys showed better results. Values of the statistical significance of the Kolmogorov-Smirnov test (KSp) point at the accordance of distribution of analysed motor variables of the both sub-samples.

Table 1 Distribution of BMI for boys and girls

\begin{tabular}{lccc}
\hline Mass & Percentiles & Boys $\left(\mathrm{kg} / \mathrm{m}^{2}\right)$ & Girls $\left(\mathrm{kg} / \mathrm{m}^{2}\right)$ \\
\hline Underweight & $<5$ & $<13.80$ & $<13.50$ \\
& & $(\mathrm{~N}=7-4.86 \%)$ & $(\mathrm{N}=4-2.83 \%)$ \\
Normal mass & $5-85$ & from 13.81 to 17.39 & from 13.51 to 17.59 \\
& & $(\mathrm{~N}=90-62.50 \%)$ & $(\mathrm{N}=96-68.09 \%)$ \\
Pre-obese & $85.01-95$ & from 17.40 to 19.20 & from 17.60 to 19.60 \\
& & $(\mathrm{~N}=28-19.44 \%)$ & $(\mathrm{N}=25-17.73 \%)$ \\
Obese & $<95.01$ & $>19.21$ & $>19.61$ \\
& & $(\mathrm{~N}=19-13.20 \%)$ & $(\mathrm{N}=16-11.35 \%)$ \\
\hline
\end{tabular}

Table 2 Descriptive statistics and gender differences

\begin{tabular}{llccccc}
\hline Variable & Gender & AS & S & KSp & f & p \\
\hline \multirow{2}{*}{ Hand tapping (freq.) } & Boys & 19.74 & 3.31 & 0.41 & \multirow{2}{*}{0.55} & \multirow{2}{*}{0.46} \\
& Girls & 20.05 & 3.69 & 0.13 & & \\
\hline \multirow{2}{*}{ Flamingo (freq.) } & Boys & 3.33 & 1.34 & 0.53 & \multirow{2}{*}{3.50} & \multirow{2}{*}{0.06} \\
\hline \multirow{2}{*}{ Sit and reach test (cm) } & Girls & 3.04 & 1.28 & 0.36 & & \\
\hline \multirow{2}{*}{ Standing long jump (cm) } & Goys & 17.76 & 5.18 & 0.11 & \multirow{2}{*}{1.47} & \multirow{2}{*}{0.23} \\
\hline \multirow{2}{*}{ Sit-ups in 30 s (freq.) } & Boys & 18.48 & 4.80 & 0.19 & & \multirow{2}{*}{0.00} \\
\hline \multirow{2}{*}{ Shuttle run test 10x5 m (s) } & Girls & 117.84 & 18.59 & 0.59 & \multirow{2}{*}{$11.14 *$} & \multirow{2}{*}{0.00} \\
& Girls & 18.13 & 3.63 & 0.07 & \multirow{2}{*}{$10.49 *$} & \multirow{2}{*}{0.00} \\
\hline
\end{tabular}

Legend: AS - arithmetical mean, $\mathrm{S}$ - standard deviation, CV - coefficient of variance, $\mathrm{KSp}$ - level pf statistical significance of Kolmogorov Smirnovljev coefficient $f$ - univariant $f$ test; $p$ - level of statistical significance $\mathrm{f}$ test; $\mathrm{F}$ - multi variance Wilkson's $\mathrm{F}$ test; $\mathrm{P}$ - statistical significance of the multivariate $\mathrm{F}$ test; * - statistical significant difference at the level $\mathrm{p}<0.0001$.

By analysing the data in table 3, and taking into account Pillai's Trace values of the multi-variant test, it has been concluded that there is no statistically significant difference $(\mathrm{P}=0.53)$ between the respondents of different levels of nourishment, neither among the boys nor girls $(\mathrm{P}=0.19)$ considering their motor skills, observing the whole system of the applied variables. There were no individual differences determined either. 
Table 3 Group differences

\begin{tabular}{|c|c|c|c|c|c|}
\hline Variable & Gender & $\mathrm{f}$ & $\mathrm{p}$ & PT & $\mathrm{P}$ \\
\hline \multirow{2}{*}{ Hand tapping } & Boys & 1.43 & 0.24 & \multirow[t]{6}{*}{0.94} & \multirow[t]{6}{*}{0.53} \\
\hline & Girls & 1.58 & 0.20 & & \\
\hline \multirow{2}{*}{ Flamingo } & Boys & 0.63 & 0.60 & & \\
\hline & Girls & 0.57 & 0.64 & & \\
\hline \multirow{2}{*}{ Sit and reach test } & Boys & 0.55 & 0.65 & & \\
\hline & Girls & 0.94 & 0.43 & & \\
\hline \multirow{2}{*}{ Standing long jump } & Boys & 1.82 & 0.15 & \multirow[t]{6}{*}{1.39} & \multirow[t]{6}{*}{0.13} \\
\hline & Girls & 0.99 & 0.40 & & \\
\hline \multirow{2}{*}{ Sit-ups $30 \mathrm{~s}$} & Boys & 2.17 & 0.10 & & \\
\hline & Girls & 0.64 & 0.59 & & \\
\hline \multirow{2}{*}{ Shuttle run test $10 \times 5$} & Boys & 0.01 & 0.99 & & \\
\hline & Girls & 2.42 & 0.07 & & \\
\hline
\end{tabular}

Legend: $f$ - univariant $f$ test; $p$ - level of statistical significance of $f$ test;

PT - multi-variant Pillai's Trace test; P - statistical significance of multi-variant PT test.

When the sample is unequal. i.e., the number of cases in the cells (groups), robust, Pillai's Trace coefficient is taken as a more precise descriptor of multivariate statistics.

Tables 4 and 5 show Bonferroni's comparison between the groups of respondents at the level of statistical significance $(p<0.0125)$ for boys and girls.

Considering the fact that the whole system of variables did not have statistically significant differences either among the boys or girls, using Post Hoc tests between the groups of respondents, depending on their state of nourishment, differences between two genders were not expressed.

\section{DISCUSSION}

The main results of this research of boys and girls aged 7-8, point at the fact that most of the children in the samples of both are normally nourished, and that they have a similar longitudinal dimension of the skeleton and body mass, and that they have average values of the BMI. It can be said that there is a greater percentage of boys in comparison to girls who belong to the category of obese at risk and obese, but this percentage is satisfactory. This is the consequence of an earlier phase of the intensive growth and development in girls and this is manifested by greater values of the longitudinal dimension and growth of bones into length. The research results are totally opposite with the findings by Wang \& Lobstein (2006). The authors state that Serbia is among those countries with increased prevalence of obesity in children. We should state that these data are at least 12 years old. The problems of overnourishment in Serbia are more obvious in adults as stressed by Živić, Ćirić \& Stanković (2011). The authors also stress that until 2000, more than one half of the whole population of Serbia had weight problems. More precisely, 54\% of adults are overnourished, and $36.7 \%$ belong to the category of nearly obese, and $17.3 \%$ to the category of obese. Prevalence of obese children in Serbia is estimated at 19\%. The research results of Pelemiš, Pelemiš, \& Branković (2015) in Serbia, on the territory of Belgrade, for a sample of younger children, point at the fact that significant differences were 
Table 4 Differences among the boys of the same group

\begin{tabular}{|c|c|c|c|c|}
\hline Variable & $\begin{array}{c}\text { (I) groups according to } \\
\text { BMI }\end{array}$ & $\begin{array}{l}\text { (J) Groups according } \\
\text { to BMI }\end{array}$ & $\begin{array}{c}\text { Difference } \\
\text { AS (I-J) }\end{array}$ & pBon \\
\hline \multirow{6}{*}{ Hand tapping } & Underweight & Normal mass & 0.080 & 1.000 \\
\hline & \multirow{4}{*}{ Normal mass } & Pre-obese & -1.331 & 1.000 \\
\hline & & Obese & 0.240 & 1.000 \\
\hline & & Pre-obese & -1.411 & 0.304 \\
\hline & & Obese & 0.161 & 1.000 \\
\hline & Pre-obese & Obese & 1.572 & 0.670 \\
\hline \multirow{6}{*}{ Flamingo } & Underweight & Normal mass & 0.438 & 1.000 \\
\hline & \multirow{4}{*}{ Normal mass } & Pre-obese & 0.637 & 1.000 \\
\hline & & Obese & 0.707 & 1.000 \\
\hline & & Pre-obese & 0.200 & 1.000 \\
\hline & & Obese & 0.270 & 1.000 \\
\hline & Pre-obese & Obese & 0.070 & 1.000 \\
\hline \multirow{6}{*}{ Sit and reach test } & Underweight & Normal mass & -1.003 & 1.000 \\
\hline & \multirow{4}{*}{ Normal mass } & Pre-obese & 0.393 & 1.000 \\
\hline & & Obese & -0.541 & 1.000 \\
\hline & & Pre-obese & 1.396 & 1.000 \\
\hline & & Obese & 0.462 & 1.000 \\
\hline & Pre-obese & Obese & -0.934 & 1.000 \\
\hline \multirow{6}{*}{ Standing long jump } & Underweight & Normal mass & -8.934 & 1.000 \\
\hline & \multirow{4}{*}{ Normal mass } & Pre-obese & -1.871 & 1.000 \\
\hline & & Obese & -1.632 & 1.000 \\
\hline & & Pre-obese & 7.062 & 0.475 \\
\hline & & Obese & 7.302 & 0.715 \\
\hline & Pre-obese & Obese & 0.240 & 1.000 \\
\hline \multirow{6}{*}{ Stand-ups in $30 \mathrm{~s}$} & Underweight & Normal mass & -0.400 & 1.000 \\
\hline & \multirow{4}{*}{ Normal mass } & Pre-obese & 1.321 & 1.000 \\
\hline & & Obese & 1.128 & 1.000 \\
\hline & & Pre-obese & 1.721 & 0.170 \\
\hline & & Obese & 1.527 & 0.565 \\
\hline & Pre-obese & Obese & -0.194 & 1.000 \\
\hline \multirow{6}{*}{ Shuttle run test $10 \times 5$} & \multirow[t]{3}{*}{ Underweight } & Normal mass & 0.129 & 1.000 \\
\hline & & Pre-obese & 0.103 & 1.000 \\
\hline & & Obese & 0.207 & 1.000 \\
\hline & \multirow[t]{2}{*}{ Normal mass } & Pre-obese & -0.026 & 1.000 \\
\hline & & Obese & 0.078 & 1.000 \\
\hline & Pre-obese & Obese & 0.104 & 1.000 \\
\hline
\end{tabular}

Legend: Group (I) - groups according to BMI; : Group (J) - groups according to BMI; Differences AS (I-J) - values of differences of arithmetical means; pBon-statistical significance of the Bonferroni test at the level $\mathrm{p}<0.0125$. 
Table 5 Differences among the girls of the same group

\begin{tabular}{|c|c|c|c|c|}
\hline \multirow[t]{2}{*}{ Variable } & \multicolumn{2}{|c|}{ (I) groups according to $(\mathrm{J})$ Groups according to } & \multirow{2}{*}{$\begin{array}{c}\text { Difference } \\
\text { AS (I-J) }\end{array}$} & \multirow[t]{2}{*}{ pBon } \\
\hline & BMI & BMI & & \\
\hline \multirow{6}{*}{ Hand tapping } & \multirow[t]{2}{*}{ Underweight } & Normal mass & 2.369 & 1.000 \\
\hline & & Pre-obese & 3.463 & 0.492 \\
\hline & \multirow{3}{*}{ Normal mass } & Obese & 3.507 & 0.538 \\
\hline & & Pre-obese & 1.094 & 1.000 \\
\hline & & Obese & 1.138 & 1.000 \\
\hline & Pre-obese & Obese & 0.044 & 1.000 \\
\hline \multirow{6}{*}{ Flamingo } & \multirow[t]{2}{*}{ Underweight } & Normal mass & 0.225 & 1.000 \\
\hline & & Pre-obese & 0.252 & 1.000 \\
\hline & \multirow{3}{*}{ Normal mass } & Obese & 0.653 & 1.000 \\
\hline & & Pre-obese & 0.027 & 1.000 \\
\hline & & Obese & 0.428 & 1.000 \\
\hline & Pre-obese & Obese & 0.401 & 1.000 \\
\hline \multirow{6}{*}{ Sit and reach test } & \multirow[t]{2}{*}{ Underweight } & Normal mass & 2.833 & 1.000 \\
\hline & & Pre-obese & 3.980 & 0.760 \\
\hline & \multirow{3}{*}{ Normal mass } & Obese & 3.375 & 1.000 \\
\hline & & Pre-obese & 1.147 & 1.000 \\
\hline & & Obese & 0.542 & 1.000 \\
\hline & Pre-obese & Obese & -0.605 & 1.000 \\
\hline \multirow{6}{*}{ Standing long jump } & \multirow[t]{3}{*}{ Underweight } & Normal mass & 0.586 & 1.000 \\
\hline & & Pre-obese & 6.608 & 1.000 \\
\hline & & Obese & 8.188 & 1.000 \\
\hline & \multirow[t]{2}{*}{ Normal mass } & Pre-obese & 6.022 & 1.000 \\
\hline & & Obese & 7.601 & 1.000 \\
\hline & Pre-obese & Obese & 1.580 & 1.000 \\
\hline \multirow{6}{*}{ Stand-ups in $30 \mathrm{~s}$} & \multirow[t]{2}{*}{ Underweight } & Normal mass & -2.000 & 1.000 \\
\hline & & Pre-obese & -2.090 & 1.000 \\
\hline & \multirow{3}{*}{ Normal mass } & Obese & -0.687 & 1.000 \\
\hline & & Pre-obese & -0.090 & 1.000 \\
\hline & & Obese & 1.313 & 1.000 \\
\hline & Pre-obese & Obese & 1.403 & 1.000 \\
\hline \multirow{6}{*}{ Shuttle run test $10 \times 5$} & \multirow[t]{2}{*}{ Underweight } & Normal mass & 2.939 & 0.298 \\
\hline & & Pre-obese & 1.699 & 1.000 \\
\hline & \multirow{3}{*}{ Normal mass } & Obese & 2.134 & 1.000 \\
\hline & & Pre-obese & -1.240 & 0.358 \\
\hline & & Obese & -0.805 & 1.000 \\
\hline & Pre-obese & Obese & 0.435 & 1.000 \\
\hline
\end{tabular}

seen only in longitude dimensions with higher average values for boys, and that sub samples do not differ significantly and that they have a normal state of nourishment with average values of BMI for both genders. Also, newer research done by Pavlica, Rakić, \& Sironjić (2017) on the territory of Vojvodina show greater values of the longitude dimension and lowering of BMI among children aged 6.50 to 7.49 in comparison to previous periods. Valuable research was done by Aycan (2009), and it shows that in the whole world, in the first decade of the $21 \mathrm{st}$ century, annual prevalence of overnourishment has increased to $6 \%$ in almost all age groups. Problems with overweight appear at an increasingly earlier age and it is thought that more than $10 \%$ of world 
population of school children are overweight (Seidell, 2005). Essentially, it can be concluded that changed body structure leads to non-normal biomechanics of movement in some segments of the body, then to clumsiness and to inhibition in creating motor patterns, which results in restrictions in some segments of motor leaning in children (Sarkar, Singh, Bansal, \& Kapoor, 2011), and this was not the case in our sample. It should be stressed that girls have more fat tissues than boys (Roshe, Heymsfield, Lohman, 1996), and that the chemical contents of fat change during life. Nevertheless, a cell of fat tissue is filled with a drop of neutral fat, which pushes the nucleus and cytoplasm into the part of the station membranes. During aging, there is an increase in adipose and non-fat tissue of both genders.

Observing the respondents according to gender, we observed the dominance of boys concerning explosive strength of the lower extremities, repetitive strength of the body and agility. Expressing a greater level of strength, agility and explosion cannot be connected into a relation with the way of life of children, socio-economical conditions and facts that children take part in some sports in their free time or maybe experience motor testing even earlier. Using biological potentials of children is different, considering the fact that there is a different influence of social surroundings in the phase of most intensive growth and development. We should not neglect the individuality of growth and development of a child's body, its maturation and this can have a direct influence on motor functions, and means maturation of the centres in the cerebral cortex, maturation of afferent and efferent paths, development of autonomous paths. Factors of social environment such as: social standard, cultural level, place and the role of physical education in it, can influence the development of motor and cognitive abilities, as well as the morphological and connective characteristics of children, demonstrated in the aspect of the difference between the genders. Habits of boys and girls of the same age are different. Boys spend more time outdoors playing (different activities with balls: for example football, climbing trees, imitating their heroes). In these activities, endurance is dominant (long term physical activities), explosive strength of the legs and speed of running. Heterogeneous life habits of children of different genders can influence the existence of differences in expressing motor abilities manifested by different levels of strength expression and other motor abilities, and this is in accordance with the findings of Carlos et al. (2014). Research result connected to agility confirm the findings of Halasi \& Lešpeša (2012) who proved a higher level of coordination and agility of boys in comparison to girls of the same age. The results are also connected with the findings of Fratric et al. (2012), in which differences in gender concerning motor abilities were identified at all ages from 7 to 10. Transformations of motor abilities and activities of children of a younger school age, regardless of gender differences, always appear in accordance with some morphological and functional determiners. These changes are mostly manifested in the muscular, bone-ankle and other systems. This kind of differentiations can be much easier or more difficult for the realisation of suitable motor moving tasks and they appear in each individual in accordance with his or her body growth and development. Due to this fact and for the purpose of eliminating the influences of such habits, diets and environmental influence, the authors tried to point to some differences in the motor area of children of different genders of and different states of nourishment. The influence of social factors on participation in physical activities of children can be strongly expressed during the younger school age, but it need not depend on the level of nourishment. This 
was proved by the research on the factors influencing participation of children in school activities in relation to the weaker and better socio-economic status of the environment it is being developed in (Heersink \& Volpe, 2004; Neves et al., 2005; Matsudo et al., 2006). Nevertheless, the latest findings of the research done by DuBose, Gross McMillan, Wood, \& Sisson (2018) show that BMI scores were not directly connected to motor skills, but authors also stress that the estimated levels are positively connected to motor skills.

The practical value of the paper lies in the initial evaluation of motor skills and state of nourishment of children and this could form the initial basis of following growth and development of children attending primary school. According to the very significant information about the initial state of relevant characteristics and abilities gained from the findings of this research, teachers can plan physical education classes, according to real values of children, and to select children according to their BMI values. The availability of the results to the students and parents can be a strong motivational tool for the further physical activities of children in class and outside it. Considering the fact that during development and growth relations between motor abilities and morphological characteristics change, checking at different ages should be done. Results of the evaluation of health status can be used as an aid both to teachers and students in planning learning and activities in further work (Ayers \& Sariscsany, 2011). Feedback necessary for planning and programming physical education classes can be obtained by testing the state of physical fitness. Results of the research stress the significance of early encouragement of motor development and a healthy lifestyle in children. This stimulation of motor development of children is characterized by regular physical activities and healthy eating. The optimal level of motor activities, well developed fundamental motor skills and a healthy body structure are of a great significance for health, quality of life connected to health and general wellbeing of children.

\section{CONCLUSION}

It can be said the findings obtained in this research are encouraging, considering the fact that most of the samples are in the normal state of nourishment, although it is possible that obesity influences weaker development of motor abilities, and it is also concluded that the mass of children of both genders does not determine their motor abilities. There are no significant changes in the sub samples influenced by the values of BMI. We further suggest analysing the relation between the motor abilities and BMI of both genders, because the obtained information about the fact when BMI determines motor behavior of children should be valuable. We should also study the levels of physical activities of children and their influence on motor performance. In this way we should plan and realise precise intentions by the planned physical activities in further overcoming the weakening of motor abilities.

Acknowledgements: This work was generated within the framework of the "The Concepts and strategies of providing quality basic education and upbringing" (179020) project, funded by the Ministry of Education and Science of the Republic of Serbia. 


\section{REFERENCES}

Aycan, Z. (2009). Obesity in childhood: Definition and epidemiology. Journal of Clinical Research in Pediatric Endocrinology, 1(S1), 44-53.

Ayers, S., \& Sariscany, M.J. (2011). The Physical Best teacher's guide. Physical education for lifelong fitness (3rd ed.). Boston: NA: National Association for Sport and Physical Education.

Burdyukova, E.V., Pustovalov, D.A., Oranskaya, A.N., Pertsov, S.S., \& Gurevich, K.G. (2012). Mechanisms of maladaptation to physical exercise in Moscow shoolchildren. Bulletin of Experimental Biology and Medicine, 153(4), 428-430.

Bryant, E.S., Duncan, M.J., Birch, S.L. (2014). Fundamental movement skills and weight status in British primary school children. European Journal of Sport Science, 17(7), 730-736.

Carlos, M., Marinho, D., Casanova, N., Fonseca, T., Vila-Cha, C., Jorge, B., et al. (2014). Gender's effect on a school-based intervention in the prepubertal growth spurt. Journal of Human Kinetics, 12(43), 159-167.

Centers for Disease Control and Prevention. (2000). Measuring healthy days. Atlanta, Georgia: CDC. Retrieved January 26, 2016 from the World Wide Web http://www.cdc.gov/hrqol/.

Chiodera, P., Volta, E., Gobbi, G., Milioli, M.A., Mirandola, P., \& Bonetti, R. (2008). Specifically designed physical exercise programs improve children's motor abilities. Scandinavian Journal of Medicine \& Science in Sports, 18(2), 179-187.

Council of Europe (1993). Eurofit: Handbook for the Eurofit Tests of Physical Fitness. Strasbourg: Council of Europe.

DuBose, K.D., Gross McMillan, A., Wood, A.P., \& Sisson, S.B. (2018). Joint relationship between physical activity, weight status, and motor skills in children aged 3 to 10 years. Perceptual and Motor Skills. doi: 10.1177/0031512518767008.

Fratrić, F., Orlić, D., Badža, V., Nešić, M., Goranović, K., \& Bojić, I. (2012). Relations between intellectual and motor abilities in younger school children. Facta Universitatis Series Physical Education and Sport, 10(1), 49-57.

Halasi, S., Lepeš, J. (2012). Razlike u motoričkim sposobnostima i telesnoj kompoziciji između dečaka i devojčica od 7 godina (Differences in motor skills and body composition between boys and girls of 7 years). Sportske nauke i Zdravlje, 2(1), 75-79. In Serbian

Heersink, J.L., \& Volpe, S.L. (2004). Assessment of physical activity in children of low income status in Western Massachusetts. Medicine \& Science in Sports\& Exercise, 36(5), S111-S112.

Jakšić, D. (2016). Efekti primene kinezioloških tretmana na motoričke, morfološke i intelektualne dimenzije predškolske dece (Effects of application of kinesiological treatments on motor, morphological and intellectual dimensions of preschool children). Doctoral dissertacion. Novi Sad: Faculty of Sport and Physical Education, University of Novi Sad. In Serbian

Janssen, I., Katzmarzyk, P.T., \& Ross, R. (2004). Waist circumference and not body mass index explains obesity-related health risk. The American Journal of Clinical Nutrition, 79(3), 379-384.

Malina, R.M., \& Katzmarzyk, P.T. (2006). Physical activity and fitness in international growth standard for preadolescent and adolescent children. Food and Nutrition Bulletin, 27(4), 295-313.

Matsudo, V.K., Andrade, E.L., Matsudo, S.M., Araujo, T.L., Guedes, J.S., Andrade, D.R., et al. (2006). Changes in levels of physical activity according to socio-economic level, after five years of an intervention program. Medicine \& Science in Sports \& Exercise, 38(5), S369.

Mendonça, C.P., \& Anjos, L.A. (2004). Dietary and physical activity factors as determinants of the increase in overweight/obesity in Brazil. Cadernos de Saúde Pública, 20(3), 698-709.

Musalek, M., Kokstejn, J., Papez, P., Scheffler, C., Mumm, R., Czernitzki, A.F., et al. (2017). Impact of normal weight obesity on fundamental motor skills in pre-school children aged 3 to 6 years. Anthropoligischer Anzeiger, 74(3), 203-212.

National Association for Sport and Physical Education-NASPE (2002). Active start: A statement of physical activity guidelines for children birth to 5 years. Oxon Hill, MD: AAHPERD Publications.

National Institutes of Health. National Heart, Lung, and Blood Institute (1998). Clinical guidelines on the identification, and treatment of overweight and obesity in adults: The evidence report. Obesity Research, 6(2), 51-209.

Neves, R.C., Araujo, T.L., Cruciani, F., Andrade, E.L., Matsudo, S.M., \& Matsudo, V.K. (2005). Impact of a fiveyear intervention program on physical activity level of a low socio-economic region. Medicine \& Science in Sports \& Exercise, 37(5), S248-S249.

Pavlica, T., Rakic, R., \& Sironjic, T. (2017). Changes in morphological characteristics during the period 20052014 in a sample of Serbian 7 - year-old children. International Journal of Morphology, 35(2), 691-697. 
Pelemiš, V., Macura, M., Andevski-Krivokuća, N., Ujsasi, D., Pelemiš, M., \& Lalić, S. (2015). Influence of aerobic training on the biochemical and physical parameters of obese women. Facta Universitatis Series Physical Education and Sport, 13(2), 217-228.

Pelemiš, V., Pelemiš, M., \& Branković, P. (2015). Dimorfic differences in body composition of pre-school children. In S. Pantelić (Ed.), Proceedings Book of 18 Scientific Conference "FIS Comunications 2015" in Physical Education, Sport and Recreation, 15th - 17th October 2015, (pp. 160-165). Niš: Faculty of Sport and Physical Education, University of Niš.

Pelemiš, V., Branković, P., \& Banović, M. (2016). State nutrition of pre-school children. Sports Science and Health, 6(2) 129-134.

Pišot, R., \& Planinšec, J. (2010). Motor structure and basic movement competences in early child development. Annales Kinesiologiae, 1(2), 145-165.

Pelemiš, V., Macura, M., \& Branković, P. (2017). Sex differences in morphological characteristics of preschool children. The Anthropologist, 30(2), 153-160.

Planinšec, J., \& Matejek, Č. (2004). Differences in physical activity between non-overweight, overweight and obese children. Collegium Antropologicum, 28(2), 747-754.

Roshe A., Heymsfield S., Lohman, T. (1996). Human body composition. Champaign Illinois: Human Kinetics.

Sarkar, A., Singh, M., Bansal, N., \& Kapoor, S. (2011). Effects of obesity on balance and gait alterations in young adults. Indian Journal of Physiology and Pharmacology, 55(3), 227-233.

Seidell, J. C. (2005). Epidemiology of obesity. Seminars in Vascular Medicine, 5(1), 3-14.

Šekeljic, G. (2014). Teorija i metodika fizičkog vaspitanja 1 (Theory and methodology of physical education I). Užice: Faculty of Pedagogy, University of Kragujevac. In Serbian

Strong, W.B., Malina, R.M., Limkie, C.J.R., Daniels, S.R., Dishman, R.K., Gutin, B., et al. (2005). Evidence based physical activity for school-age youth. Journal of Pediatrics, 146(6), 732-737.

Tucker, P. (2008). The physical activity levels of preschool-aged children: A systematic review. Early Childhood Research Quarterly, 23, 547-558.

Warburton, D.E., Nicol, C.W., \& Bredin, S.S. (2006). Health benefits of physical activity: The evidence. Canadian Medical Association Journal, 174, 801-809.

Wang, Y., \& Lobstein, T. I. M. (2006). Worldwide trends in childhood overweight and obesity. Pediatric Obesity, 1(1), 11-25.

World Health Organization-WHO (2000). Obesity: preventing and managing the global epidemic. Technical Report Series, 894. Geneva: WHO.

World Health Organization-WHO (2008). Childhood overweight and obesity. Retrieved January 26, 2016 from the World Wide Web: http://www.who.int/dietphysicalactivity/childhood/en/.

World Medical Association Declaration of Helsinki. (2013). Ethical Principles for Medical Research Involving Human Subjects, 64th WMA General Assembly, Fortaleza, Brazil, October 2013. Retrieved January 27, 2016 from the World Wide Web: http://www.wma.net/en/30publications/10policies/b3/index.html.

Živić, S., Ćirić, V., \& Stanković, S. (2011). Epidemiološke karakteristike i etiopatogeneza gojaznosti dece i adolescenata (Epidemiological characteristics and etiopatogenesis of obesity in children and adolescents). Medicinski glasnik Specijalna bolnica za bolesti štitaste žlezde i bolesti metabolizma Zlatibor, 16(39), 4049. In Serbian

\section{ANALIZA MOTORIČKOG STATUSA DECE MLAĐEG ŠKOLSKOG UZRASTA U ODNOSU NA NJIHOV NUTRITIVNI STATUS}

Cilj istraživanje bio je da se utvrdi da li postoje polne razlike dece mlađeg školskog uzrasta, kao $i$ razlike unutar subuzoraka prouzrokavane stanjem uhranjenosti u motoričkim sposobnostima. Ukupan uzorak sačinjavalo je 285 ispitanika starosti $7.27 \pm 0.43$ godine, od toga 144 dečaka (50.52\%), te 141 devojčice (49.48\%) koji su pohađali prvi razred osnovne škole na teritoriji AP Vojvodine (Republika Srbija). Rezultati istraživanja ukazuju da je zastupljenost pothranjene dece u celokupnom uzorku mala $3.87 \%$; normalno uhranjene iznosila je 65.26\%; rizično gojaznih bilo je $18.59 \%$ i gojaznih svega $12.28 \%$, te da su polne razlike u motoričkim sposobnostima na nivou celokupnog uzorka, kada se zanemari njihovo stanje uhranjenosti, ispoljene $u$ korist boljih prosečnih vrednosti dečaka $u$ 
eksplozivnoj snazi donjih ekstremiteta, repetitivnoj snazi trupa i agilnosti. Unutar subuzoraka, statistički značajne razlike u pogledu motoričkih spsobnosti nisu uočene niti kod dečaka različitog stepena uhranjenosti, niti kod devojčica. Nalazi istraživanja ukazuju da postoji zadovoljavajući procenat normalno uhranjene dece, te da linearnost njihovog stanja uhranjenosti teče u skladu sa njhovim rastom i razvojem. Njihov motorički razvoj unutar subuzotraka takođe teče ujednačeno, a polne razlike prisutne su radi diferencijacije motoričkih sposobnosti koja nastaje u ovom periodu. Autori smatraju da je veće razlike $i$ varijabilitete u pogledu stanja uhranjenosti i motorike moguće očekivati u predpubertetskom periodu.

Ključne reči: indeks telesne mase, razlike, pol, motoričke sposobnosti 